\title{
Krótkie omówienie monografii: Miriam Laclavíková, Adriana Švecová, Dejiny právnického vzdelávania na Trnavskej univerzite v Trnave, Praba: Leges 2017, 160 ss.
}

\author{
Abstract \\ A Short Discussion of Miriam Laclavíková and Adriana Švecová's Monograph \\ Dejiny právnickébo vzdelávania na Trnavskej univerzite v Jrnave, Praha: Leges 2017, \\ $160 \mathrm{pp}$.
}

The monograph is an introduction to the history of the teaching of law in Trnava during the existence of the university (1667-1777, and subsequently since 1998) and during the functioning of the Royal Law School (1777-1784). Among the issues analyzed were the circumstances of the establishment of the Faculty of Law at the University of Trnava in 1667, curricula with particular emphasis on the study of Hungarian law, and the significance of the juridical works of the university's professors. The work emphasized how Corpus Iuris Hungarici, a two-volume collection of Hungarian law (vol. 1 contains Tripartitum by Štefan Werbőczy), was developed and published in Trnava (1696), where advanced studies in the area of criminal law were also conducted.

Keywords: Hungary, Slovakia, Trnava, university, faculty of law, law teaching, Corpus Iuris Hungarici, Tripartitum

Słowa kluczowe: Węgry, Słowacja, Trnawa, uniwersytet, wydział prawa, nauczanie prawa, Corpus Iuris Hungarici, Tripartitum

Monografia słowackich autorek, badaczek Katedry Historii Prawa Uniwersytetu Trnawskiego w Trnawie, jest syntetycznym wprowadzeniem do historii nauczania prawa na tym uniwersytecie. Jak wielokrotnie zaznaczały Autorki, dużym problemem w badaniach nad dziejami Wydziału Prawa w Trnawie jest brak źródeł, zwłaszcza o charakterze narracyjnym (s. 53-54). Nasuwa się tutaj podobieństwo z Uniwersytetem Krakowskim. W 1719 roku rozległy pożar strawił Kolegium Prawnicze i pochłonął rękopisy, skutkiem czego badania nad dziejami krakowskiego Wydziału Prawa w okresie wcześniejszym są bardzo utrudnione. Autorki omawianej rozprawy opierały się na bogatej literaturze, 
przede wszystkim słowackiej i węgierskiej, źródłach wydanych oraz archiwaliach przechowywanych na Uniwersytecie oraz w Węgierskim Archiwum Narodowym, gdzie przechowywane są akta dotyczące zakonu jezuitów (zob. s. 157).

Klarowny układ książki odpowiada czterem etapom dziejów nauczania prawa w Królestwie Węgierskim: do powstania Wydziału Prawa w Trnawie (rozdział 1); dalej lata 1667-1777, kiedy to wraz z istnieniem (od 1635) Uniwersytetu w Trnawie funkcjonował na nim fakultet prawa (rozdział 2), następnie krótki okres siedmiu lat (17771784), w którym, po przeniesieniu Uniwersytetu do Budy, w Trnawie działała Królewska Akademia Prawnicza. Jej translacja do Bratysławy na ponad 200 lat zamknęła okres nauczania prawa w Trnawie. Dopiero odnowienie Uniwersytetu pozwoliło w roku 1998 na ponowne otwarcie Wydziału Prawa (rozdział 4).

Główną ideą książki jest ukazanie realizacji w praktyce jednego z podstawowych celów, który przyświecał założeniu Wydziału Prawa na trnawskiej wszechnicy - nauczania prawa węgierskiego. Już w rozdziale 1 Autorki zwróciły uwagę na praktykę dwuletniego nauczania prawa w kancelariach adwokackich doby późnego średniowiecza (tzw. patravia, s. 19-21). Próby wprowadzenia nauczania prawniczego na Węgrzech na szczeblu uniwersyteckim w średniowieczu nie powiodły się (Pecz, Stara Buda, Bratysława). Jednocześnie Autorki zwróciły uwagę, że nauczanie uniwersyteckie opierano na prawie rzymskim i kanonicznym, gdy tymczasem zjawisko romanizacji w prawie węgierskim w zasadzie nie nastąpiło - w monografii posłużono się terminem pseudoromanizacji (s. 27). Zaskakujące, że - podobnie jak w Królestwie Polskim - ślady romanizacji obecne są przede wszystkim w miastach, gdzie, tak jak w Polsce, pozostawała w użyciu Summa legum brevis, levis et utilis Mistrza Rajmunda (s. 28). W zakresie prawa ziemskiego szczególną rolę odgrywała spisana przez Štefana Werböczego Tripartita, będąca w znacznej mierze kodyfikacją prawa zwyczajowego.

Na Wydziale Prawa w Trnawie, uniwersytecie działającym pod kontrolą zakonu jezuitów, utworzono trzy katedry prawa: rzymskiego, kanonicznego oraz węgierskiego (s. 44). Fakultet formalnie powstał 2 stycznia 1667 roku, a więc kilkadziesiąt lat po założeniu uniwersytetu (1635), pierwotnie składającego się z wydziałów filozoficznego i teologicznego, funkcjonujących zgodnie z jezuickim Ratio studiorum (s. 37-38). Pierwotną materialną podstawą wydziału były zapisy testamentowe arcybiskupów ostrzyhomskich (Imrich Lóši oraz Juraj Lipai, s. 47-49), jednakże potrzeby finansowe były znacznie większe. Problemy z utrzymaniem wydziału prowadziły do redukcji zajęć i liczby profesorów w I połowie XVIII wieku z trzech do dwóch (s. 58). Autorki relacjonują przebieg zasady organizacji studiów oraz metodę nauczania, polegającą przede wszystkim na wykładzie (s. 55-56); nadzór nad edukacją prawa świeckiego (prawo rzymskie i węgierskie) stanowił kompetencję kapituły ostrzyhomskiej (s. 49). Wiek Oświecenia i reformy edukacji prawniczej w myśl oświeconego absolutyzmu to kolejny, istotny rozdział w historii fakultetu prawniczego w Trnawie. Nacisk na wykład prawa lokalnego, powiązanie prawa rzymskiego z wykładem prawa natury, podział wykładu prawa węgierskiego na prawo materialne i procesowe to tylko niektóre ze zmian wprowadzanych po 1760 roku (s. 62 i n.). Na organizację nauczania w Trnawie miały wpływ przekształcenia na uniwersytecie wiedeńskim (s. 66-68), a niebagatelną rolę w reformie szkolnictwa wyższego odegrała kasata zakonu jezuitów (s. 71-72). Ostatecznie w 1777 roku cały uniwersytet został przeniesiony do Budy, a w jego miejsce powołano Królewską Akademię 
Prawniczą. Była ona nastawiona na szkolenie kadr dla administracji państwa działającego w duchu oświeconego absolutyzmu, a wykładane przedmioty nie ograniczały się wyłącznie do prawniczych, lecz obejmowały także przykładowo finanse i statystykę (s. 75, 115). Funkcjonowała w Trnawie zaledwie przez siedem lat, ponieważ w 1784 roku została przeniesiona do Bratysławy. Wśród zagadnień poruszanych przez autorki znalazły się także problemy z zachowaniem dyscypliny przez studentów i ich konflikty z mieszkańcami Trnawy (s. 40), niemniej uniwersytet gwarantował miejscowości rozwój przez 150 lat swego istnienia, a jego przenosiny do Budy i likwidacja Królewskiej Akademii Prawniczej kilka lat później przyczyniły się do stagnacji miasta w kolejnych dziesięcioleciach (s. 118-119). Ostatni rozdział, 4, omawia powstanie Wydziału Prawa w 1998 roku na odnowionym Uniwersytecie Trnawskim oraz dynamikę jego rozwoju.

Jak wspomniano na wstępie, zamysłem Autorek było uwypuklenie znaczenia wykładu prawa węgierskiego, co udało się im przekonująco przedstawić. Potwierdzają to zarówno przytaczane programy zajęć i sama struktura wydziału, jak i przede wszystkim analiza przedmiotu badań zatrudnionych tam profesorów. W obliczu braku innych źródeł to właśnie starodruki dzieł prawniczych oraz nielicznie zachowane rękopiśmienne notatki do wykładów stanowią znakomite źródło do badania myśli prawniczej w dobie nowożytnej. W omawianej monografii tematyce tej poświęcono sporo miejsca (s. 79-109). Uderzające jest to, że prace uwzględniające prawo węgierskie pisane były nie tylko przez profesorów katedry prawa węgierskiego, ale także zatrudnionych w katedrach prawa rzymskiego i kanonicznego. Autorki zdecydowały się omówić twórczość prawniczą wespół z podaniem podstawowych danych biograficznych ich autorów. Wśród zagadnień, które zostały szczególnie uwypuklone jako dowód istotnego znaczenia trnawskiego ośrodka prawniczego, było opracowanie dwutomowego korpusu prawa węgierskiego (Corpus Iuris Hungarici, 1696) oraz studia nad prawem karnym. Corpus Iuris Hungarici zawierało w tomie pierwszym Tripartite, a w drugim dotychczas rozproszone inne akty normatywne, które ukazały się w XVI i XVII wieku. Synteza ta stała się niezbędnym instrumentem w praktyce prawniczej i była wznawiana. $Z$ kolei studia nad prawem karnym zmierzały do jego modernizacji i polegały między innymi na opracowaniu adaptacji austriackich regulacji do lokalnych potrzeb (s. 83-84).

Reasumując, opracowanie jest poręczną syntezą dziejów nauczania prawa w Trnawie. Niewątpliwie jego cenną wartością jest analiza dorobku profesorów prawa XVII i XVIII wieku oraz ukazanie znaczenia wykładu prawa węgierskiego w XVII i połowie XVIII wieku. Nie była to reguła - na innych uniwersytetach (choćby w Krakowie) prawo lokalne w edukacji uniwersyteckiej, jakkolwiek obecne, nie miało zagwarantowanej tak silnej pozycji jak w Trnawie, gdzie wraz z powstaniem Wydziału Prawa od razu przewidziano dedykowaną mu odrębną katedrę. 